\section{UNUSUAL NEST SITE OF COMMON GRACKLE}

by Jim Slimmon, Saskatoon

On June 1, 1962, while browsing through the dead reeds near the end of "Hudson's Bay Slough," near the airport in Saskatoon, and while seeing many nests of Redwinged Blackbirds and Yellow-headed blackbirds, I discovered a nest of the Common Grackle. I have never known this species to nest in redwing or yellowhead sites before. The nest was roughly 16" above the water, built among, and attached to last year's dead reeds. It contained five eggs. Within fifteen feet a second such nest was located. When I returned on June 9 , one egg had hatched, the young was growing well, and the other four eggs were apparently infertile. I took a colored picture at this time. I returned some days later with Dr. S. Houston; the young ibird had apparently flown. We took the nest with the infertile eggs for future reference.

\section{NEST PROTECTION OF THE AMERICAN WIDGEON}

by Jim Slimmon, Saskatoon

On May 26, while visiting a troop at the Pike Lake Boy Scout Campsite, I was shown a nest which had been identified by Alec Dzubin of Canadian Wildlife Service as an American Widgeon. The nest was roughly 100 feet from water, near a small group of high trees which stood by themselves halfway between the bush area of the campsite and the water. It was close to an old log and hidden under dense grass. The 9 eggs' were typically creamy colored.

On June 14, while again visiting the campsite I decided to see if the hatch had been completed. I discovered, after getting wet feet before getting very many feet from the bush area, that the water had risen considerably, probably from both the heavy rains and the pumping which had been taking place. I had to put on rubber boots to get out to the nest site.

On parting the heavy grass, I found 4 eggs a few inches below the surface of the water, one of them partly floating. Below these were 2 more, below that were 2 more, and on the bottom was the last egg. All were imbedded in dead grass. It was obvious that the duck, as the water had risen, had kept pulling in more grass and building the nest up higher. Although it was difficult to make sure below water, it appeared that she had used more than the immediate material she could have reached from the nest. She was not able to keep all the eggs coming up with the nest. At the top level, her courage in fighting the elements had finally deserted her and she left the nest.

\section{GO EASY ON THE DUCKS}

The United States Department of the Interior news release of June 25, 1962 , reports that its waterfowl survey teams find the duck breeding population lower than in any year since the surveys began in 1951. They report a $37 \%$ decrease in the duck breeding population in southern Alberta, Saskatchewan and Manitoba. This is somewhat offset by improved water and habitat conditions in the Dakotas and in Minnesota.

The southern portions of the Prairie Provinces are said to yield, in normal years, 50 to 80 per cent of the total continental duck population. The Prairie Provinces are even more important if only the Mallards, Pintails, Blue-winged Teal, Canvasback and Redhead are considered; for 75 to 95 per cent of these are produced here. These species collectively make up approximately two-thirds of the total duck kill in an average year.

Do not kill more ducks than you need, for the duck population is dangerously low. Be especially careful that you do not shoot any Canvasback or Redhead.

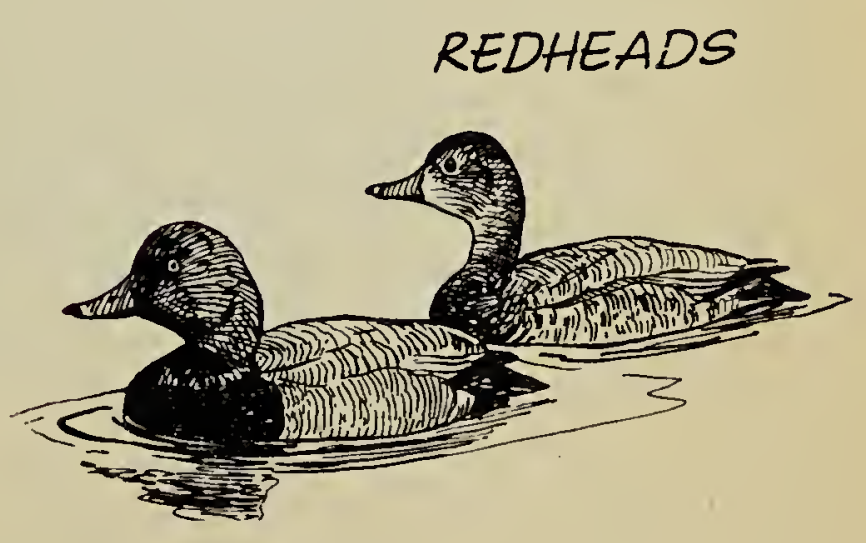

